Review

\title{
Consumer Education as an Important Condition for Increasing Wild Animal Meat Consumption in The Context of Promoting the Idea of Sustainable Development in Poland
}

\author{
Dominika Mesinger*, Aneta Ocieczek \\ Faculty of Entrepreneurship and Quality Science, Gdynia Maritime University, Gdynia, Poland
}

Received: 18 December 2019

Accepted: 3 February 2020

\begin{abstract}
This paper analysed the need for fundamental education of consumers to create attitudes and behaviours favouring the promotion of the idea of sustainable development and sustainable consumption. The methodology applied included the use of logical analysis of secondary data available in research, plus normative and legal literature. The analysis of gathered data indicated that a reduction of adverse environmental effects of livestock farming and meat production could be achieved by increasing the focus on consumer education, in particular on the risk of mass production. Game meat in Poland is beginning to enter the next product life cycle very slowly and gradually through the promotion of meat products. If these measures are continued at the present level, consumer acceptance of this type of meat could increase. At the same time, it was found that appropriate education of the population and building a sense of social responsibility may allow for the introduction of positive changes in hunting management, e.g., the marketing of fresh meat.
\end{abstract}

Keywords: venison, hunting, sustainable development, sustainable consumption, product life cycle

\section{Introduction}

Beginning in the mid-20 th century, rapid economic development in the West has contributed to a high level of prosperity, lasting until today - particularly in Western Europe and North America. This involves many benefits, but also certain consequences mostly related to the overproduction and overconsumption of goods, which results in excessive exploitation of the

*e-mail: d.mesinger@wpit.umg.edu.pl natural environment and its systematic destruction. The negative effects of an apparently favourable situation include a constantly growing mass volume of agricultural production, both as regards plants and animals, leading to excessive emissions of methane and ammonia to the atmosphere, environmental pollution, a significant reduction of ecosystem biodiversity, a reduction of freshwater resources, eutrophication of water reservoirs, overfishing, soil impoverishment and climate change. This problem was identified in the 1970s, which resulted in initiating studies on the notion of "sustainable development". The definition of sustainable development has been outlined at 
the highest legal levels, provided for in Art. 5 of the Constitution of the Republic of Poland, and described in detail in the Environmental Protection Law as social and economic development integrating political, economic and social activities, while preserving the natural balance and the sustainability of essential processes in the environment to ensure that the needs of both present and future generations can be met [1]

The aim of this paper was to emphasize the role of education of society as regards creating attitudes conducive to the implementation of the idea of sustainable development. The subject of the discussion was the consumption of the meat of wild animals as an expression of increased awareness of its nutritional and health quality and care for the welfare of our planet and future generations.

\section{Methods}

The methodology applied in the paper included the use of a systematic analysis of research, normative and legal literature, including 1) the genesis of the terms "sustainable development" and "sustainable consumption", 2) characteristics of the sources of the ecosystem equilibrium destabilisation associated with food production and consumption, 3) characteristics of the quality parameters of wild animal meat in the context of the sustainable consumption idea, and 4) identification of factors determining consumer behaviours in the food market, together with 5) potential methods of their modification.

The principal objective of our paper was to demonstrate that the creation of favourable conditions for implementing the concepts of moderation and diversity may constitute a starting point for improving the quality of life and environment in Poland through rational hunting management, which should be based on the specific predispositions of the Polish customer.

\section{Genesis of the Concepts}

Successful effects of applying the idea of sustainable development became the grounds for creating the concept of "sustainable consumption", which was defined in 2010 by the FAO (Food and Agriculture Organization of the United Nations) as a method of nutrition with the least possible environmental impact, ensuring the best possible health status of the present and future generations. A diet prepared according to the idea of sustainable consumption must be 1) protective and respectful of ecosystems and their natural biodiversity, 2) nutritionally adequate as regards body requirements, 3) culturally acceptable, 4) safe and healthy and 5) physically accessible and economically fair, while optimizing available natural and human resources [2, 3].

Meat is primarily used in order to ensure an adequate amount of high-quality protein in the human diet. The increasing prosperity of societies makes meat no longer a luxury commodity, but a common product. This fact results from constant intensification of animal production. It should be stressed that intensive production has contributed to a decrease in prices of slaughter animals and birds, causing an increased risk to the natural environment.

\section{Sources of Ecosystem Destabilisation}

Livestock produce large amounts of greenhouse gases, such as carbon dioxide, nitrous oxide and methane. It is assumed that the greenhouse potential of methane is 23 times higher than that of carbon dioxide, while that of nitrous oxide is assumed to be 296 times higher than that of carbon dioxide. Greenhouse gases emitted during animal production account for $14.5-18 \%$ of global emissions. Even $80 \%$ of greenhouse gases emitted in agriculture are related to animal production.

The source of emitted methane is animal intestinal fermentation, and its amount depends on the amount, type and composition of feed intake as well as on the animal species. Poultry emits less methane than pigs because their feed contains less dietary fibre and, additionally, digestion in the large intestine in poultry is less intense than in pigs.

The source of nitrous oxide emitted to the atmosphere is the anaerobic decomposition of excrement, nitrification and denitrification of organic nitrogen. Livestock do not produce nitrous oxide directly, but it is formed as a result of the decomposition of organic compounds in animal faeces. This means that the emission of this greenhouse gas is an inevitable result of animal production. It is worth emphasizing that nitrous oxide is also emitted by agriculturally utilized soils because of their nitrogen, mineral and organic fertilization and due to cattle grazing.

Carbon dioxide emitted in the breathing process of animals accounts for up to $21 \%$ of the greenhouse gas balance emitted by humans, but it is considered neutral since it is circulated in nature.

In comparing the emissions of greenhouse gases in Poland in 1988 and 2012, it should be noted that although the overall production of greenhouse gases decreased, the emission of animal origin has significantly increased. It is also worth emphasizing that the greenhouse gases formed directly as a result of animal husbandry are not the only ones related to animal production. In addition, emissions related to breeding and transporting the animals to slaughterhouses, processing, packing and transporting the product to the shop must be taken into account, as each of those processes generates the production of greenhouse gases [4].

The average amounts of methane secreted by animals can be classified into three groups: pigs $0-8 \mathrm{~g}$ methane per $1 \mathrm{~kg}$ of dry matter intake, horses 2-12 $\mathrm{g}$ methane per $1 \mathrm{~kg}$ of dry matter intake, and large ruminants even $10-40 \mathrm{~g}$ methane per $1 \mathrm{~kg}$ of dry matter 
intake, depending on the feed. This differentiation results from the fact that the less susceptible the food is to fermentation, the smaller the amount of this gas secreted by the animals. The daily emission of methane per animal was classified in the following way: dairy milking cows - 200-600 g methane/day, depending on the amount of the milk produced; dry dairy cows 150-300 g methane/day; heifers - 110-250 g methane/ day; cows for fattening - 80-220 g methane/day; and goats and sheep - 5-35 g methane/day. However, there are no data concerning methane emissions by cervids. However, they can be classified as ruminants due to the presence of rumen, reticulum, omasum and abomasum. Since deer are classified as small ruminants, it is more appropriate to compare them to goats and sheep [5].

A report published by the FAO in 2013 calculated the average amount of greenhouse gases emitted by small ruminants using the example of sheep and goats. It was also calculated that in producing $1 \mathrm{~kg}$ of meat from these animals, $23.8 \mathrm{~kg} \mathrm{CO}_{2}$-eq of gases are emitted, while $1 \mathrm{~kg}$ of buffalo meat involves $53.4 \mathrm{~kg}$ $\mathrm{CO}_{2}$-eq, and $1 \mathrm{~kg}$ of beef uses $46.2 \mathrm{~kg} \mathrm{CO}$-eq. The volume of $23.8 \mathrm{~kg} \mathrm{CO}$-eq related to meat production of small ruminants, according to the report, consists of digestion with secretion of methane $(54.9 \%)$, manure, used in crops and stored, secreting nitrous oxide
$(17.6 \%)$, nutrition with secretion of carbon dioxide (11.1\%), fertilizing and harvest residues secrete nitrous oxide $(8.8 \%)$, manure producing methane and nitrous oxide (4\%), energy used directly and indirectly during the breeding, emitting carbon dioxide $(1.8 \%)$, and other farming factors emitting carbon dioxide (1.7\%). Based on these data, it can be claimed that wild animals contribute to a lower extent to emissions of greenhouse gases due to the lack of factors directly related to breeding and cultivation of plants for fodder [2].

The factor that also has to be emphasized while discussing sustainable development is the fact that hunting and acquiring game to some extent, by their very nature, fits the implementation of this idea. The game population in Poland in 2010-2018 is presented in Table 1, and game acquisition in Poland in 2010-2018 is presented in Table 2.

The data presented in tables show that no overproduction is recorded for the game population, thus no overpopulation takes place. Biodiversity is preserved while the population of animals is maintained at similar levels. The exception was the situation of wild boars in Poland, the population of which fell by more than half due to intensified shooting in the 2017/2018 hunting season related to an increased risk of African swine fever among animals.

Table 1. Game population in Poland in 2010-2018 (in thousands of animals).

\begin{tabular}{|c|c|c|c|c|c|c|c|}
\hline & 2010 & 2013 & 2014 & 2015 & 2016 & 2017 & 2018 \\
\hline Fallow deer & 23.3 & 28.2 & 28.1 & 27.5 & 28.2 & 29.0 & 29.0 \\
\hline Mouflons & 2.8 & 2.75 & 2.95 & 2.9 & 3.0 & 3.35 & 3.4 \\
\hline Red deer & 180.2 & 217.2 & 217.9 & 213.5 & 218.3 & 285.6 & 275.7 \\
\hline Roe deer & 822.0 & 875.9 & 873.5 & 867.0 & 887.1 & 945.6 & 922.4 \\
\hline Wild boar & 249.9 & 282.2 & 284.6 & 264.0 & 249.6 & 214.8 & 87.9 \\
\hline Foxes & 198.3 & 213.3 & 204.1 & 202.0 & 202.0 & 199.4 & 192.0 \\
\hline Pheasants & 462.9 & 483.8 & 480.8 & 520.3 & 525.2 & 544.0 & 525.5 \\
\hline
\end{tabular}

Source: [21, 30]

Table 2. Game acquisition in Poland in 2010-2018 (in thousands of animals).

\begin{tabular}{|c|c|c|c|c|c|c|c|}
\hline & $2010 / 2011$ & $2012 / 2013$ & $2013 / 2014$ & $2014 / 2015$ & $2015 / 2016$ & $2016 / 2017$ & $2017 / 2018$ \\
\hline Fallow deer & 6.4 & 7.5 & 8.4 & 8.6 & 9.3 & 9.6 & 9.5 \\
\hline Mouflons & 0 & 0 & 0 & 0 & 0 & 0 & 0 \\
\hline Red deer & 54.3 & 69 & 77 & 83 & 89.3 & 93.5 & 94.4 \\
\hline Roe deer & 161 & 172 & 187 & 195 & 203.4 & 213.5 & 214.8 \\
\hline Wild boar & 233 & 240 & 242 & 291 & 341 & 310 & 341 \\
\hline Foxes & 142 & 144 & 130 & 147 & 159 & 155 & 154.5 \\
\hline Pheasants & 104 & 117 & 115 & 129 & 128 & 114 & 102.4 \\
\hline
\end{tabular}

Source: [21, 30] 
Quality Parameters of Wild Animal Meat in the Context of the Concept of Sustainable Consumption

In light of striving to implement the concept of sustainable development as regards the popularization of game meat, the issue of nutritional quality of this meat also should be raised. Unquestionably, meat of wild animals is characterized by a low content of fat. For instance, the meat of deer living in the wild in Europe has an intramuscular fat content of less than $1 \%$. This indicator should be considered as particularly important in view of the obesity epidemic, which is more and more intensely growing - especially in developing European countries. For comparison, beef meat can contain up to $30 \%$ fat, both perimuscular and intramuscular. An important aspect is also the nutritional characteristics of the supplied fat. It was found that fat from the meat of wild ruminants (cervids) was characterized by a higher content of polyunsaturated fatty acids than fat in the meat of domesticated ruminants (sheep, goats). The amount of saturated fatty acids is lower in roe deer and slightly higher in deer, but these values are lower than the values recorded in farm animals. Game meat is also rich in high-quality protein and it does not contain any additional substances that are supplied to farm animals with the feed [8].

In view of the above data, a significant issue justifying the need to promote game meat consumption is the model of proper human nutrition. The most important reasons include the recommendation to significantly reduce meat consumption as compared to fish and products of plant origin [9]. At the same time, great emphasis is put on the need to increase the diversity of raw materials used. In this context, the justification for promoting wild animal meat as an alternative to that of slaughter animals should be raised. In particular, that the substance of the change would amount to replacing quantity with quality, which is clearly in line with the observed development of anti-consumption movements and subcultures, whose activity is linked to the deteriorating quality of life and the environment all over the world [10]. This, in turn, is attributed to excessive, unsustainable consumption and a rise in the consumer's position supported by information technologies [11]. Therefore, it seems to be justified to claim that higher amounts of slaughter animal meat should be replaced with lower amounts of game meat. In this way, the postulate of moderation would be implemented. Additionally, the meat of wild animals is characterized by different health values (better compared to meat of slaughter animals) [8]. In this way, the postulate of diversity would be met at the same time.

An equally important role in the promotion of wild animal meat will be played by aspects related to the utility of that meat, which is expressed in the ease of its preparation, contrary to the general opinion that wild meat is difficult to prepare [12].
The effort to implement the idea of sustainable consumption must be based on both modifications of measures specific to the producer, as well as on those related to the consumer's activity on the market of goods, who makes the final decision as regards the purchase of food. In order to gradually yet systematically implement the concept of sustainable consumption, care should be taken to ensure that the consumer shows a socially responsible attitude when purchasing meat, taking into account environmental, animal welfare and stockbreeding factors.

\section{Determinants of Consumer Behaviours in the Food Market}

Solomon et al. [13] define a consumer as a person who identifies their needs or desires and then purchases a product/service. Every day consumers make multiple decisions concerning various aspects of everyday life. The decisions are usually taken consciously, which initiates the beginning of the activity. Each consumer makes decisions in an individualised manner, focusing on a differentiated set of attributes of the product/ service and taking into account various reasons for the choice. In the case of most consumer decisions, their effect is not directly identifiable, i.e., it is not known whether the decision taken is good or bad. The consumers verify their decisions during consumption, using the product or service. The lower experience of the consumer with a given category of goods when making the purchase for the first time, if the product/ service is new, if the consumer has not had previous experience related to the product/service, the more he or she is involved in an information-based solution to the problem [14].

One of the important roles of the consumer as the decision-maker is choosing between various alternatives and examining different criteria for this choice. Market participants are involved in the communication system through consumption activities by which they can communicate their roles and statuses. The main aim of consumption can be to explore many opportunities that the market has to offer in search of "true pleasure". The consumer is, at the same time, a person who makes a choice, is a communicator, a seeker of pleasure, of identity, a victim, a rebel and an activist or an employee, and sometimes performs all these functions at the same time [15].

The consumer increasingly more often makes a choice between the food he or she knows and the one that is unknown. The term "knows" means both the fact that the consumer has knowledge and experience related to it. The "unknown", "novel" food involves such food about which the consumer has heard or not, probably has seen it, but has no experience related to it and has not tasted it.

The term "novel food" refers to food that was not consumed on a large scale in the EU before 15 May 1997. This term is used to define new sources of food 
or newly developed innovative food, produced with the use of new technologies and production processes and traditionally consumed outside the EU but not in its territory. The new Regulation [Regulation (EU) No. 2015/2283, 2015] adopted on 25 November 2015 by the European Parliament and the Council replaced the previous regulation dating back to 1997 . The new rules were applicable as of 1 January 2018. They introduce a simplified procedure for the assessment of traditional foods from third countries and which are novel in the EU. If the traditional food from third countries has a proven history of safe use and there are no objections to its safety from a member state or the EFSA, such food may be placed on the market on the basis of a notification by the applicant. The Regulation explains the term "history of safe food use in a third country", which means that the safety of a particular type of food has been confirmed with data and from experience of continued use of this food for at least 25 years in the customary diet by a significant number of people in one or more third countries prior to notification [16]. On 10 November 2016, EFSA published the results of social consultations on the guidelines concerning novel food and traditional food from third countries.

Traditional food can also be novel food and unknown to persons originating from other cultural circles [17]. Additionally, food that is traditional for specific cultural circles is replaced over time with innovations (market novelties) to return, after a relatively long period, in its original form as novelty. This condition can be referred to as the second (secondary) life cycle of the product. Application of the Life Cycle Assessment (LCA) in the context of food production assessment is currently becoming more and more common. This trend is derived from the need of both consumers and producers to have comprehensive information, enabling them to properly identify products and production practices that are environmentally and economically sustainable. Additionally, food life cycle assessment is currently consistent with ISO norms 14040 and ISO 14044, making it widely accepted in agriculture as an opportunity to evaluate the environmental impact of the production. The main advantage of the LCA is to provide a comprehensive, multifaceted knowledge of the production processes, in particular in terms of the economic efficiency of using resources and the environmental impact of production [2].

Rozin and Fallon [18] observed that an unknown object, including culturally diverse food, may raise concerns, aversion and repulsion, and the reason for such a reaction is a lack of knowledge and experience associated with it, as well as individual characteristics of a given person, including an increased level of neophobia.

Natural resources of both flora and fauna of the European climate zone have determined the sources of food. Climatic values have influenced the cultivation of specific crops (cereals, leguminous and papilionaceous plants) and breeding, among others, cattle, sheep, pigs, poultry, as well as the use of forest resources - game and fruit. Religion has been, and continues to be, an important factor influencing the type of food consumed.

\section{Modification of Determinants of Food Consumer Behaviour}

Novel, unknown or little known food cannot be the subject of spontaneous behaviours related to it since the decision to buy or to consume is taken slowly. The consumer takes into account various circumstances and can search for knowledge about it, and this is the case of intentional behaviours, i.e., purposeful and planned in relation to such food. From the consumer's perspective, novelty is a new product if the consumer considers it new. It affects the state of the consumer's stimulation and, as the gap between known and unknown increases, the degree of stimulation increases. Moderate stimulation makes the consumer stay in touch with the new object, while too high or too low repels him from the novelty, does not allow him or her to know and approve of it. Apart from the degree of stimulation, the level of anxiety also affects the exploratory activity. The willingness to explore reaches the maximum level at a minimum level of anxiety. Some persons demonstrate susceptibility to anxiety conditions and, in such cases, the willingness to explore is significantly reduced. Differences between people resulting from a differentiated level of stimulation and their susceptibility to anxiety reveal differences in their response to novelties. The willingness to explore can be increased by creating favourable conditions [19].

Berlyne [20] defined curiosity as an internal condition of increased stimulation with which a person can find himself, caused by a lack of information, knowledge, contradictions and high uncertainty with reference to the new situation. Curiosity is also an attempt to acquire new knowledge and sensual experience, which motivate cognitive behaviours. Berlyne proposed a differentiation between two types of curiosity and described them as perceptual and epistemic (cognitive). Perceptual curiosity is "curiosity which leads to increased perception of stimuli", and is evoked in animals and humans by the sense of sight, hearing or by tactile stimulation. On the other hand, epistemic curiosity was described as "drive to know", which stimulates puzzle-solving and filling in gaps of knowledge [20].

Consumers' responses to novel food, so far unknown to them are, to a significant degree, conditioned by their psychological specificity. The consumer evaluates the degree of distinctness of the novel food characteristics from those previously experienced, taking into account, among others, the benefits and the risk. A lack of experience related to the product, and often a lack of knowledge, provides a barrier to its acceptance.

The results of the research carried out in Belgium confirm that it is possible for consumers to overcome 
barriers [21]. The choices made by the consumers and their later behaviours are affected by their needs, values, attitudes, personality features or the mood felt at a given moment [22].

According to Ozimek and Gutkowska [23], food choice is influenced by numerous factors: individual preferences (I like the product, I like its taste); culture, in particular customs, tradition, religion, social pressure (the product is recommended by other persons); availability in the market (lack or excess of substitutes); functional values (convenience, easy preparation); economic aspects (price and related benefit equivalent, a consumer's income); nutritional characteristics of the product; promotional activities; and habits.

The results of the study in which consumer groups from 10 European countries were monitored in terms of their behaviour as regards the volume of purchased products demonstrated that Poles were described as "value seekers" open to new products. The purchase of novelties was determined by several factors, including taste, health and time savings. Gutkowska et al. [24] found that Polish consumers, particularly young and middle-aged persons, were positively oriented towards changes in the food market.

The choice of a particular product by the consumer is also influenced by the opinion of others, advertising, and the time required to purchase essential food products. Each consumer has his or her own hierarchy of preferences and chooses the product that best matches his or her requirements [25]. Food that will be accepted is the food expected by people, which is beneficial to health and tastes good [26].

Indirect information on the taste or benefits resulting from consuming novel food may have an impact on the reduction of the neophobia level and on the increased willingness to try it. For instance, if others say that this is tasty or good for health, people seem to be more inclined to try it [27]. However, if the food evokes disgust, positive information about health benefits and taste is usually not effective [28]. Only direct information obtained through one's own experience can have a positive impact on the neophobia level. People tend to generalize their experiences, and positive experiences with novel food reduce their overall level of neophobia [27].

Consumers significantly differ in terms of age, income, education and tastes, but also other factors such as the degree of willingness to try new products. Regardless of the type of new product, consumers can be divided into pioneers of consumption and early followers. Other consumers may accept innovations with a considerable delay. After a slow start, more and more consumers may begin to accept a new product [29].

In order to overcome a reluctance to eat insects, although traditional in Asian and African countries, researchers developed and proposed a strategy including increasing product awareness by providing consumers with information on insects as an alternative source of food [30]. It was proposed to introduce edible insects to the market and provide the consumers with the knowledge of how to prepare them [31]. The need to undertake measures aimed at increasing the level of consumer knowledge concerning relations between individual groups of animals in the systematic classification, including insects and crustaceans, was indicated [21]. It was found that the opportunities for tasting and experimental exposure of edible insects should be increased [30, 31]. Additionally, it was proposed that suitable products should be developed to not only reduce the barriers but also to highlight the good taste of edible insects [32] and to include them into known food products [21]. Recommendations also included the need to refer to such authorities as the former UN Secretary General Kofi Annan, who recommended the consumption of edible insects [33] and the popularization of entomophagy - in particular among children from a very early age [34]. All these guidelines can be used to create favourable conditions to increase game meat consumption in Poland.

Consumer education will help people to understand the factors behind higher prices of products originating from sustainable farming, and even partially replace animal products from mass farming [35]. A producer of sustainable meat can improve the use of feed, thus reducing the amount of gases emitted by cattle. Although this should be considered desirable from an ecological perspective, this type of meat will be more expensive since it is not economically viable [36].

The education of society is crucial since producers produce what consumers expect from them. Currently, since the main factor significant for the vast majority of consumers is the low price of the product, producers are focused on reducing the costs of raw materials, transport and packaging. The second key factor in consumer assessment is the brand image and, consequently, producers are investing in the development of production technology, higher efficiency of enterprise management systems, a high level of production and capital integration [37].

Global annual meat production has increased from 70 million tonnes to 290 million tonnes over the last 50 years. Pig meat accounts for a significant share of this volume, i.e., as much as $37 \%$, followed by poultry $-33 \%$, beef $-23 \%$, goat and sheep $-4.5 \%$, while game and other meat accounts for only $2.5 \%$ [24]. The above figures indicate the diversification of the meat market. The idea of sustainable consumption should be aimed at reducing such drastic divergences that exist, for example between game meat and pig meat. This phenomenon is very important in view of the fact that game meat used to be very desirable. For primitive people, meat of wild animals, along with plants, provided the staple food in subsequent stages of history until the beginning of the $19^{\text {th }}$ century, the possibility of hunting was a symbol of high social status, and game meat was frequently served by the nobility and at kings' tables. Nevertheless, game meat 
was popular in Poland not only among the nobility, but it also was often eaten by the bourgeoisie, until the law on breeding and protection of game animals and on hunting law came into force on 17 June 1959. This act gradually and effectively liquidated a culture of game consumption in Poland, leading to a drastic reduction in the market for this meat through centralized management of the purpose and export of Polish game meat to Western markets. As a result of these changes, game meat became a strange product for present-day generations [38].

\section{Summary and Conclusions}

Intensive economic development has brought about a number of negative ecological effects. Actions leading directly to intensification of meat production and to the promotion of such activities should be balanced by actions in the area of consumer education, in particular concerning the risks arising from mass food production. Game meat produced in extremely low amounts (in comparison to pork, for example) is not currently a competitive product in view of the disappearance of the tradition of eating this meat and the absence of large producers of game products. At the same time, it should be emphasized that intensification of agriculture and livestock production has a negative impact on the welfare of game animals due to the conversion of their natural habitats into arable lands, pastures or construction sites. This, in turn, leads to a reduction in the food base and limitations on the breading of wild animals, thus reducing the natural population and the systematic reduction of biodiversity.

It should be noted that not all eating habits and traditions can be changed, but some of them can be reduced, replaced and balanced, and therefore the education of society is essential. Consumer education should be based on the idea of balancing the types of consumed meat. The implementation of such an idea should lead to numerous benefits and the essence of sustainable development can be realized. The basis for sustainable development, including sustainable consumption, is to strike a balance between economic, social and environmental living conditions. This, in turn, is a part of the environmental trend that is expressed not only through the need to use food produced in accordance with strictly regulated procedures, but also through a specific approach respecting the environment, the responsibility for the living conditions of future generations and the creation of alternatives for people striving for lifestyle changes.

Continuous intensification of agriculture at a constant level undermines ecological biodiversity, which makes the protection of natural resources an essential element of long-term work on sustainable development.

The situation of wild boar meat from the 2017/2018 hunting season provides a perfect confirmation of the need to restore the tradition of eating game meat in
Poland. Animals had to be shot due to an increased risk of developing African swine fever, but the tests showed that the vast majority of animals were found to be healthy. Those carcasses could be traded, but in view of the lack of widespread tradition of eating game meat in Poland, the meat had to be frozen and exported to Western markets. If Polish consumers had accepted game meat, the meat could have been marketed as fresh meat and this would have reduced the carbon footprint related to the freezing storage of meat, since the transport of frozen meat requires not only fuel consumption but also energy for cooling vehicles.

Game meat in Poland is beginning to enter the next product life cycle very slowly and gradually through the promotion of meat products. If these measures are continued at the present level, consumer acceptance of this type of meat could increase.

\section{Conflict of Interest}

The authors declare no conflict of interest.

\section{References}

1. ŻMIJA D. Sustainable development of agriculture and rural areas in Poland. Studia Ekonomiczne, 166, 149, 2014.

2. OPIO C., GERBER P., MOTTET A., FALCUCCI A., TEMPIO G., MACLEOD M., VELLINGA T., HENDERSON B. STEINFELD H. Greenhouse gas emissions from ruminant supply chains - A global life cycle assessment. Food and Agriculture Organization of the United Nations (FAO), Rome, 2013.

3. KACZOROWSKA J., KOWRYGO B. Consumer willingness to implement a sustainable pattern of food consumption. Zeszyty Naukowe Szkoły Głównej Gospodarstwa Wiejskiego, Ekonomika i Organizacja Gospodarki Żywnościowej, 114, 33, 2016.

4. DORSZEWSKI P., GRABOWICZ M., KASZKOWIAK J., BOROWSKI S. Climate safetiness and greenhouse gas emissions from livestock. Logistyka, 5, 765, 2015.

5. FLACHOWSKY G., LEBZIEN P. Food producing animals and greenhouse gases - possibilities of animals nutrition to lower emissions. Ubersichten zur Tierernahrung, 35, 2007 [In German].

6. Site of Główny Urząd Statystyczny. Available online: https://stat.gov.pl/obszary-tematyczne/rolnictwolesnictwo/lesnictwo/lesnictwo-2017,1,13.html (accessed on 12.10.2019).

7. Site of Główny Urząd Statystyczny. Available online: https://stat.gov.pl/obszary-tematyczne/rocznikistatystyczne/roczniki-statystyczne/rocznik-statystycznylesnictwa-2018,13,1.html (accessed on 12.10.2019).

8. DASZKIEWICZ T., MESINGER D. Fatty acid profile of meat (Longissimus lumborum) from female roe deer (Capreolus capreolus L.) and red deer (Cervus elaphus L.).International journal of food properties, 21 (1), 2276, 2018.

9. Site of Narodowe Centrum Edukacji Żywieniowej. Available online: https://ncez.pl/abc-zywienia-/zasadyzdrowego-zywienia/piramida-zdrowego-zywienia-i- 
aktywnosci-fizycznej-dla-osob-doroslych (accessed on 20.07.2019).

10. PENTINA I., AMOS C. The Freegan phenomenon: anticonsumption or consumer resistence? European Journal of Marketing 45 (11/12), 1768, 2011.

11. DENEGRI-KNOTT J., ZWICK D., SCHROEDER J.E. Mapping consumer power: an integrative framework for marketing and consumer research. European Journal of Marketing, 40 (9-10), 950, 2006.

12. KWIECIŃSKA K., KOSICKA-GĘBSKA M., GĘBSKI J. Assessment of consumer preferences related to selection of venison. Handel zewnetrzny, 360 (1), 53, 2016.

13. SOLOMON M, BAMOSSY GJ, ASKEGAARD S HOGG, M.K. Consumer Behaviour: A European Perspective, $3^{\text {rd }}$ ed.; Prentice Hall: London, 2006.

14. JACHNIS A. Consumer psychology: psychological and sociological determinants of consumer behavior. Oficyna Wydawnicza Branta: Bydgoszcz-Warszawa-Lublin, 2007.

15. GABRIEL Y., LANG T. The Unmanageable Consumer, $3^{\text {rd }}$ ed.,: Sage publications: London, 1995.

16. Site of Główny Inspektorat Sanitarny. Available online: http://gis.gov.pl/images/zp/dgsante_novel-food_pl.pdf (accessed on 20.10.2019)

17. JEŻEWSKA-ZYCHOWICZ M., BABICZ-ZIELIŃSKA E., LASKOWSKI W. Consumer on the novel food market: selected consumption conditions. Wydawnictwo SGGW: Warszawa, 2009.

18. ROZIN P., FALLON A. A perspective on disgust. Psychological review, 1 (94), 23, 1987.

19. JEŻEWSKA-ZYCHOWICZ M. Selected behaviors of young consumers on the traditional food market and their determinants. Żywność Nauka Technologia Jakość, 64 (3), 126, 2009.

20. BERLYNE D. A theory of human curiosity. British Journal of Psychology. General Section, 45 (3), 180, 1954.

21. CAPARROS M.R., SABLON L., GEUENS M., BROSTAUX Y., ALABI T., BLECKER C., DRUGMAND D., HAUBRUGE É., FRANCIS F. Could Belgian Consumers Accept Edible Insects?. J Sens Stud, 29, 14, 2014.

22. MAISON D., STASIUK K. Psychological approach to understanding consumer attitudes. Problemy Zarządzania 45 (1), 18, 2014.

23. GUTKOWSKA K., OZIMEK I. Selected aspects of consumer behavior on the food market: differentiation criteria. Wydawnictwo SGGW: Warszawa, 2005.

24. GUTKOWSKA K., KOWALCZUK I., SAJDAKOWSKA M., KOZŁOWSKA A., OLEWNIK-MIKOŁAJEWSKA
A., SYLWIA ŻAKOWSKA-BIEMENS S. Consumer attitudes towards innovation on the food market. Handel Wewnętrzny, 351 (4), 80, 2014.

25. NIEWCZAS M. Food selection criteria. Żywność Nauka Technologia Jakość, 91 (6), 204, 2013.

26. ROZIN P. Social learning about food by humans. In Social learning, Psychological and biological perspectives,: T.R. Zentall and B.G. Galef. Hillsdale, NJ: ErlbaumAssociates $165,1988$.

27. PLINER P., SALVY S. Food neophobia in humans. Frontiers in nutritional science, 3, 75, 2006.

28. PELCHAT M., PLINER P. Try it. You'll like it. Effects of information on willingness to try novel foods. Appetite, 24 (2), 153, 1995.

29. KOTLER P. Marketing management, millenium edition. Jakarta: Gramedia 2002.

30. LENSVELT E., STEENBEKKERS L. Exploring consumer acceptance of entomophagy: a survey and experiment in Australia and the Netherlands. Ecology of food and nutrition 53 (5), 543, 2014.

31. LOOY H., DUNKEL F., WOOD J. How then shall we eat? Insect-eating attitudes and sustainable foodways. Agriculture and human values, 1 (31), 131, 2014.

32. DEROY O., READE B., SPENCE C. The insectivore's dilemma, and how to take the West out of it. Food Quality and Preference, 44, 44, 2015.

33. VAN HUIS A., VAN GURP H., DICKE M. The Insect Cookbook. New York: Columbia University Press, 2014.

34. TRANTER H. Insects creeping into English diets: introducing entomophagy to school children in a provincial town. Norwich: University of East Anglia, School of Biological Sciences pp.19-29, 2013.

35. GRZYBOWSKA-BRZEZIŃSKA M., GRZYWIŃSKARAPCA M. Organic food market in the aspect of the development of the phenomenon of conscious consumption. Handel wewnętrzny, 373 (2), 168, 2018.

36. MROCZEK J., RUDY M., STANISŁAWCZYK R. Meat production and consumption and sustainable development. AURA, 3, 8, 2019.

37. KOCISZEWSKI M., SZWACKA-MOKRZYCKA J. Conditions for the development of the food industry after Poland's accession to the EU. Problemy rolnictwa światowego, Wydawnictwo SGGW: Warszawa, Tom 11 (XXVI), 2011.

38. POPCZYK B. Venison trading problems. In Problemy współczesnego łowiectwa w Polsce, $1^{\text {st }}$ ed.; D. Gwiazdowicz, Oficyna wydawnicza G\&P: Poznań 137, 2012. 